\title{
TRANSLATION AS AN INDEPENDENT SCIENCE: THE LINGUISTIC ASPECT OF INTERCULTURAL COMMUNICATION
}

\section{Naima Khabibullaevna Khaitbaeva}

Senior Lecturer Interfaculty Department of The Russian Language National University Of Uzbekistan Named After Mirzo Ulugbek

\section{ABSTRACT}

This article discusses the translation of this article plays an active role in strengthening the interethnic foundations of all national cultures, establishing and developing friendly relations between the fraternal peoples of our country, as well as a powerful factor not only as a means of communication, but also its linguistics, methodology and terminology.

KEYWORDS:- translation, number of peoples and number of languages, linguist, terminology, national culture, philology, representative, original.

\section{INTRODUCTION}

Translation of works of art, drama and prose, scientific and popular books in various fields of science, diplomatic documents, official newspapers, articles by politicians and speeches by speakers, newspaper materials that speak different languages from one language to another need the services of an interpreter. The meaning of the concept of translation is very broad.

The translated work must conform to the standard of the language to be translated, and the message conveyed in the original must be as complete, clear, and effective as the original language. Translation - from the Persian word "tarzabon" into Arabic ("Tarzabon" means beautifully speaking, "orator"). Uzbek writers have expressed such a concept using terms such as inversion.

\section{Material And Methods}

Typically, translation is the reproduction of a text written in one language or a speech spoken in another language. In this sense, translation serves as a means of interethnic communication between peoples. What distinguishes nations? As you know, language is one of the most important characteristics of a nation. Because all people belonging to a particular nation speak their own (one) language However, there is no reason to conclude that the more nations there are in the 
world, the more languages. In other words, the number of peoples and the number of languages are not always proportional to each other. Because many nations can also speak the same language

For example, English is spoken not only by the British themselves, but also by other peoples living in different parts of the world, including Americans, Scots, Australians, New Zealanders, Northern Ireland and some other peoples. For example, German is the mother tongue not only of Germans, but also of Australians, Germans, Swiss, Alsatians and Luxembourgers.

Translation plays an active role in strengthening the interethnic basis of all national cultures, in the establishment and development of friendly relations between the fraternal peoples of our country. It is not only a means of communication, but also a powerful factor in one's own linguistics, methodological and terminological enrichment.

Especially in the current era, it is difficult to imagine the development of a multinational culture without translation into an age in which cooperation, solidarity, mutual and comprehensive relations between peoples are increasing every year.

Literature and translation are of national importance in the upbringing of a new generation, therefore our writers work a lot in the field of translation.

There are four conflicting laws in translation:

1. What translation theory should look like? Whether to build on a literary basis or develop on a linguistic basis?

2. What should be the nature of the translation: should it be translated verbatim or should it be a free creative translation?

3. How to give the national identity a reflection in the original. Should the translation be given national characteristics characteristic of another language, or should it be given its own national standard?

4. Everything can be learned, everything can be translated, or, on the contrary, a language is not a model of thought, but a unique perception of the world in a unique way, so that it cannot be translated from one language to another.

Translator A.D. Schweitzer in his article "Problems of linguistic research of the translation process" argues that it is important to find, define and develop the linguistic direction of translation theory. In linguistic research in recent years, much attention has been paid to translation problems. As a necessary tool for the development of translated languages, it accelerates their development, increases and improves vocabulary. And this gives the reader an opportunity to compare the original and the translation, to make the right choice when reading fiction, to give an assessment.

Translation enriches the spiritual life of a person, reveals the possibilities of the native language enriches it. Therefore, one of the most pressing problems of linguistics today is translation. Lexical translation problems occupy the first line. Translation is one of the most ancient types of human activity, thanks to which we can clearly imagine the history of human development in all its details.

Although the theory of translation in our country as an independent philological direction began to take shape mainly in the 50 s of the twentieth century, the practice of translation goes back several thousand years. It should not be concluded from this that the translation was created without theory for a thousand years.

Results and discussion

Translation, which has a long history and stages of development, was recognized as an 
independent science only by scientists and linguists around the world in the twentieth century. By the middle of the twentieth century, translation science began to develop. The founders of science are excellent translators $\mathrm{V}$. Komissarov, A. Fedorov, L. Barkhudarov, Retsker, Schweitzer, Minyar-Beloruchev, Y. Naida, Y. Munen, G. Salomov, Y. Sharipov, N. Vladimirova, Naum Grebnev and others, their work is worthy of respect.

One of the representatives of the constellation of translators is Naum Grebnev. Born November 20, 1921 in Harbin into a Jewish family, father - Isai Nakhimovich Rambakh (1886-1931), editor of the Russian-language Soviet newspaper (Vperyod, Tribuna) in Harbin in 1919-1924, from July 1926 in Moscow - worked in the Soviet Trade Fleet, then in the All Khimprom (All-Union Association of the Chemical Industry "All Khimprom" of the Supreme Council of the National Economy of the USSR), died in September 1931 in Moscow.

Mother, Leia Iosifovna Rambakh (née Galberg, 1899-1991), Elizaveta Iosifovna in everyday life, was a teacher of foreign languages and a translator, including in the Foreign Commission of the Writers' Union, gave English lessons during the years of evacuation in Tashkent. With her participation, at first in absentia, Grebnev's acquaintance with Anna Akhmatova began.

The Great Patriotic War found Grebnev from the very beginning, since at that time he served on the border, near Brest. He retreated together with the Red Army, got into the famous Kharkov (Izyum-Barvenkovo) encirclement, where the Germans captured 130 thousand Red Army soldiers, left one of the few, crossed the Seversky Donets, fought at Stalingrad, was wounded three times, and after the last wound on January 12, 1944, the war ended for him. He titled his memories of the war "The war was the most serious event in my biography". Naturally, in his translation of Rasul Gamzatov's poem "Cranes" (which became the words of a famous song), he also included his own experience of war.

After the war, Grebnev studied with Gamzatov at the Literary Institute, and since then their friendship and cooperation began. In 1949 he graduated from the Literary Institute. Grebnev also translated the poetry of the poet's father, Gamzat Tsadasa.

In 1951 he was criticized by M. Bubennov in the article "Do we need literary pseudonyms now?" for using a pseudonym.

Отец Небесный, раб Твой незаметный

Взывает к милости Твоей несметной:

Прошу: мне по грехам не воздавай!

Не расточай Свой правый гнев ответный,

Меня за прегрешенья не карай!

Из всех, кто смертен здесь и кто бессмертен,

Лишь Ты один велик и милосерден.

И хоть я шел по ложному пути,

Я смерти убоялся, и, лукавый,

Злой враг меня склонил на путь кровавый,

Я все-таки молю Тебя: «Прости!»

Heavenly Father, your invisible servant

It appeals to your countless mercy:

Please: do not repay me for my sins!

Do not squander your right anger in response,

Don't punish me for my sins!

Of all who are mortal here and who are immortal,

You alone are great and merciful.

And even though I was on the wrong path,

I was afraid of death, and, crafty,

The evil enemy led me to the bloody path, 
CURRENT RESEARCH JOURNAL OF PEDAGOGICS 2(5): 32-36, May 2021

DOI: https://doi.org/10.37547/pedagogics-crjp-02-05-06

ISSN 2767-3278

(C)2021 Master Journals

\section{Crossref do) 81 Google}

Accepted 21 ${ }^{\text {th }}$ May, 2021 \& Published $26^{\text {th }}$ May, 2021

I still pray to you: "Forgive me!"

(Translation by Naum Grebnev)

Among his translations were contemporary poets Gamzat Tsadasa, Rasul Gamzatov, Kaisyn Kuliev, Alim Keshokov, Tanzilya Zumakulova, Irakli Abashidze, Shota Nishnianidze, Ivan Tarba, Konstantin Lomia, Adam Shogentsukov.

He translated the classics of the poetry of the East, such as the Uzbek classical poets Furkat, Turdy, Makhmur, Uvaysi, Agakhi; Karakalpak classic poet Berdakh, Turkmen classical poets Zelili, Makhtumkuli, Myataji.

"The truth: The Words of the Persian and Tajik Peoples, Their Poets and Wise Men" (1968), translated by N. Grebnev, his wife, graphic artist Noemi Moiseevna Grebneva, as well as a lover of poetry and Bible repetition for children. Noemi Moiseevna designed a number of translation books by Naum Grebnev.

One of her most successful works was the book "Truth. Sayings of the Persian and Tajik peoples, their poets and sages", on the cover of which there is a vertical black key on a white background, the book includes the sayings of Alishah Ragib Samarkandi, Abu Shukur Balkhi, Anvari, Ansari, Anushirvan, Asadi Tusi, Attar, Aukhadaddin Aukhadi, Bedil, Beykhaki, Ghazali, Jami, Amir Khosrov Dahlavi (Dehlavi), Zebunniso, Kisai, Kamola Khujandi, Manuchekhri, Muizzi, Masudi Marvazi, Navoi, Omar Khayyama, Rudaki, Rumi, Saadi, Saiba Tabrizi, Sayido, Sanai, Ubeida Zakani, Unsuri, Farrukhi, Kazahni Hussein Vaiz Kashifi, Khusrawi, Shahid Balkhi, Shakir Bukhari.

Back in 1963, Korney Chukovsky wrote about Naum Grebnev:

"Before the reader he has a great merit: by long and hard work, he created, one after the other, two important books - two anthologies of folk poetry. One of them included hundreds (not tens, but hundreds!) Of songs of various Caucasian peoples, translated by him, and the other one is just as richly represented, only in his translations, Central Asian folklore: Uzbek, Tajik, Kyrgyz, Turkmen, Uyghur, Karakalpak songs.

It is usually only a large group of poets who can compile such extensive collections of oral folklore monuments and reproduce them in another language. The collections compiled by Grebnev are the fruit of his sole labor. He is not only a translator of all the songs, but also the most diligent collector of them, not only a poet, but also a research scientist". Rasul Gamzatov's poem "Cranes", translated by Grebnev, gained incredible popularity thanks to the song "Cranes" performed by Mark Bernes, which was first performed in 1969. Soon after its appearance, memorial complexes began to be erected, monuments to those who died in the Great Patriotic War with the image of flying cranes and the text of the first lines of the song.

Later, new monuments with cranes appeared, although without poetry.

R. Gamzatova translated by N.I. Grebnev. This is the memorial complex in St. Petersburg. The stele with black cranes, erected near the former theater center on Dubrovka, has no inscriptions. After the song "Cranes", the image of cranes became a symbol of memory of the victims.

Grebnev believed that there were two teachers in Russian poetry had each translation to the end: Samuel Marshak and Boris Pasternak.

From the Uzbek language he translated the famous works of Agakhi "Other words", Selected; Maksud Sheikhzade "Mirzo Ulugbek" (historical tragedy) 1967; "Origins and Mouths" 1983; "Folk Lyrics of Uzbekistan", 1959. Niyazi Kh. Kh. "Long live the Soviets! (Poem)" 1979; Turdy, Selected Works 1951; Uvaysiy "Lyrics" 1984, "Stubborn Kasym” Funny verses, 1959

Conclusion 
CURRENT RESEARCH JOURNAL OF PEDAGOGICS 2(5): 32-36, May 2021

DOI: https://doi.org/10.37547/pedagogics-crjp-02-05-06

ISSN 2767-3278

(C)2021 Master Journals

Crossief do) 88 Google

Accepted 21 ${ }^{\text {th }}$ May, 2021 \& Published 26 $6^{\text {th }}$ May, 2021

Translation is an instrument of internationalism and friendship of peoples. Regardless of which side of social life you look at, in this we see the life-giving effect of translation. Its unique influence is felt everywhere: in language, thinking, cultural, literary life, art. Translation is widespread in Uzbekistan.

In general, even today, relations between foreign countries and the Uzbek people are developing day by day. Practice and theory of translation, directions, types of translation, genres - all these are complex interrelated problems. One of the main components of this integral problem is the problem of training translators. The quality of translations cannot be improved without solving this problem.

\section{REFERENCES}

1. Faizullaeva R. National flavor and literary translation. - Moscow: 2000. - P. 54.

2. Fedorov A.V. Fundamentals of the General Theory of Translation. - "High School" Moscow: - 1983.- P. 304.

3. Khachaturian N. Realia and translatability. Tranlation skills. - 1972. - P. 42. 